\title{
А.В. Карабыков
}

\section{ЯЗЫК АДАМА, ЕВРОПЕЙСКИЙ НАЦИОНАЛИЗМ И ПОДЬЁМ РЕНЕССАНСНОЙ КОМПАРАТИВИСТИКИ ${ }^{1}$}

\begin{abstract}
Рассматривается одно из направлений адамического проекта, развитого в ренессансной культуре и нацеленного на то, чтобы воссоздать первозданный язык человечества. Сторонники этого направления стремились исследовать Ursprache через нахождение его рудиментов в известных исторических языках. Доказывается, что способы обоснования прав того или иного языка считаться адамическим или, чаще, близким его дериватом были в цеелом универсальными.

Ключевые слова: история лингвистической мысли, теории лингвогенеза, этимология, кратилизм, Книга Бытия, гебраизм, Горопий Бекан, Ричард Верстеган.
\end{abstract}

\section{Введение}

Обратившись к адамическому проекту - умственному движению XVXVII вв., вдохновлённому мечтой о реставрации первозданного языка человечества, начнём с краткого определения его объекта и самой общей схемы развития. Первозданным назывался язык, которым владели люди в Раю, в состоянии изначального совершенства. Не являясь - по крайней мере, всецело - искусственной системой произвольно и условно установленных знаков, этот праязык (Ursprache), на взгляд многих в ту эпоху, был непосредственно причастен к структуре мироздания, так как имел своё основание в природе самих вещей и/или отличался эпистемологическим совершенством, позволявшим схватывать и выражать их сущность наиболее полным и точным образом. По этой причине, как думали многие эзотерики, данный язык обладал способностью к прямому воздействию на бытие и мог служить первостепенным орудием магии.

Схему развития адамического проекта можно представить так: начавшись с доказательства первичности определённого языка (стратегия I «обосновать»), он прошёл через поиск знаковой системы Адама (стратегия II «найти») и завершился разделением на мистическом (стратегия III «npuнять» в качестве дара свыше) и рационалистском (стратегия IV «создать» искусственную замену) путях. Оба последних направления строились на представлении о том, что первозданный язык всецело потерян и не может быть восстановлен, по крайней мере усилиями человека [1].

\footnotetext{
${ }^{1}$ Работа выполнена при поддержке Российского фонда фундаментальных исследований (РФФИ), проект № 18-011-00601 «“Книга Природы” в контексте герменевтических стратегий Возрождения и раннего Нового времени».
} 
В этой статье речь пойдёт о поисках первозданного языка, составивших содержание стратегии II («найти»). Дав её сжатый очерк, я сконцентрируюсь на одном из двух её векторов. Он был связан с историкосопоставительным исследованием языков, главную роль в котором играла традиционная этимология. Рассматриваемые в ретроспективе, этот тип исследований и соответствующая стадия в истории науки о языке именуются предкомпаративизмом (precomparativism). Будут рассмотрены основные формы осуществления этой прекомпаративной линии: гебраистская, националистские и мистическая - с учётом их внутренней вариативности, позволяющей различать в двух первых «сильную» и «слабую» версии, а в их рамках более частные разновидности.

Обращаясь к истории вопроса, считаю нужным различить в ней два взаимосвязанных аспекта. Один касается исследования предкомпаративизма XVI-XVII вв. - этапа в истории лингвистики, который до недавнего времени почти не привлекал внимание учёных, исходивших из линейнопрогрессистской модели развития науки и потому считавших его лишённым научной значимости. Изменения начались в последней трети ХX в., когда за новаторскими работами Дж. Меткалфа последовали труды Дж. Эроса, Дж. Феллмана, Д. Дройкса, М.-Л. Демоне и т.д. Все они были нацелены на реконструкцию теоретико-методологических принципов, которыми руководствовались предкомпаративисты Ренессанса ${ }^{1}$. Этим трудам недоставало широты социокультурного контекста, который позволил понять причины радикальной странности языковедческого мышления той эпохи. Стремлением заполнить этот пробел вдохновлены исследования позднейших, в особенности современных, авторов: Л. Формигари, Дж. Консидайна, Д. Дел Белло, М. Травони, У. Пула, Т. Ван Хала, и т.д. Многие из них выходят за рамки собственно лингвистической историографии в междисциплинарную сферу интеллектуальной истории. Второй аспект причастен к изучению адамического проекта XV-XVII вв., опыт которого ещё более свеж и скромен, чем анализ ренессансной лингвистики. Ключевыми в этой области являются работы А. Кудэрт, У. Эко, Дж. Боно, О. Помпо, М. Олендер и немногих других учёных. Будучи по преимуществу историко-философскими и культурологическими штудиями, они, как правило, отличаются недостаточной проработанностью теоретиколингвистической стороны адамических поисков того времени. В этой статье я предлагаю рассмотреть наследие ренессансных языковедов в свете рефлексии над сущностью и участью первоязыка человечества, которая прослеживается в этом наследии, позволяя вписать его в одно из направлений адамического проекта. Такой подход обещает способствовать лучшему пониманию ренессансного “стиля” мышления о языке, а также созданию оригинальной классификации многообразных концепций, объединённых понятием предкомпаративизма.

1 Обзор работ в сфере историографии прекомпаративной лингвистики XVIXVIII вв. см.: [2. P. 5 (n. 5)]. 
Предметом исследования служат воззрения западноевропейских филологов XVI-XVII вв. на историю языка в разнообразии его национальных форм, факторы и презумпции, обусловившие специфику этих взглядов, а также способы обоснования тождества или сугубой генетической близости одной из данных форм первоязыку человечества. Основным материалом анализа стали историко-филологические трактаты К. Гесснера, Т. Библиандера, А. Кирхера, Г. Бекана, Р. Верстегана, Г. Штирнхильма и других учёных.

\section{Обзор исследуемой стратегии}

В зависимости от того, где полагали обрести ключи к языку Адама, стратегия II «найти» делилась на два направления. В согласии с первым (Iа) полем в поиске праязыка должны помочь доступные языки и тексты, где, как считали его приверженцы, «рассыпаны осколки» Ursprache, из которых - при наличии верных метода и теории - можно воссоздать целое. В свете второго извода (IIb) путь к первозданному языку, казалось, лежал через исследование знаков (сигнатур), начертанных от века Творцом в вещах и стихиях природы. Предполагалось, что, будучи познанными, сигнатуры могут быть неким образом переведены в единицы языка, отличного от всех известных наречий тем, насколько точно и полно он отражает природу творений. Сторонники этого взгляда считали, что именно так действовал сам Адам, когда давал имена животным (Быт. 2:19-20), и что есть возможность повторить его ономатопоэтический путь. Вместе с тем преобладавшая тенденция состояла в том, чтобы сближать, а не противопоставлять эти линии. Не так уж редко их поддерживали одни и те же интеллектуалы, отдавая приоритет одному варианту, но не теряя из виду другой.

Помимо внутренней сложности, анализ стратегии II («найти») затрудняется тем, что на практике она обычно дополнялась иными адамистическими элементами. Так, каждое из её направлений имело характерное дополнение. Те, кто чаял подойти к первоязыку через существующие наречия (Iа), как правило, привлекали элементы стратегии I, образуя комплекс «найти, чтобы обосновать». Дело в том, что сторонники этой линии - к ним относились пионеры сравнительно-исторической лингвистики, чуждые мистицизма, - руководствовались определённой мифоисторической схемой. В соответствии с ней им был известен часто не первозданный язык, а некий ближайший его отпрыск, генеалогически связывавший с ним все позднейшие наречия. И главной заботой этих учёных был поиск позитивных лингвистических данных, которые бы подтверждали правильность этой схемы. Тем, что нужно было доказать прежде всего, являлось наличие у «ближайшего отпрыска» уникальных черт, которые сближали его с Ursprache и отличали от всех остальных наречий. В свою очередь адвокаты пути Адама, ведшего от природных вещей и знаков к именам первоязыка (IIb), были лишены такого мифоисторического «компаса». Они стояли перед вопросами, которые грозили оказаться неразрешимыми: как именно 
можно распознать и объяснить сигнатуры совершенным образом и как затем перевести извлечённое из них знание в систему имён по примеру Адама? Это нередко побуждало их привлекать стратегию III. Создавая комплекс «принять, чтобы найти», они возлагали надежды на сверхъестественное озарение, которое только и могло помочь разрешить эти загадочные вопросы.

Возвращаясь к первой линии стратегии II, мы оказываемся перед вопросом: если главной формой работы в ней был комплекс «найти, чтобы обосновать», то почему он должен быть рассмотрен здесь, а не в русле исходной стратегии I «обосновать»? Это тем больше нуждается в прояснении, что в обоих случаях речь могла идти об одном и том же языкепретенденте. Им был иврит. Из всего спектра форм осуществления этого комплекса гебраизм являлся самой влиятельной, и он же доминировал над всеми вариантами стратегии I. Так в чём состояло различие двух разновидностей гебраизма и, если брать шире, стратегий IIа и I? Прежде всего оно касалось способов обоснования. По убеждению каббалистов, этих главных адвокатов гебраистской формы стратегии I, идея адамичности иврита подтверждается метафизикой и мифоисторией, представленными в их доктрине [3]. Единственным, что оставалось сделать, чтобы понудить тех, кто не считался с Каббалой, принять эту идею, являлась активация эпистемического и магического потенциала иврита. Что же касается историко-лингвистического изучения данного языка, то, как стало ясным во второй половине XVI в., когда академическая гебраистика сделала шаг вперёд, оно нанесло урон столь дорогим для каббалистов представлениям о радикальной инаковости иврита [Там же. С. 191-192]. Напротив, приверженцы гебраизма по линии стратегии ІІа придавали решающее значение именно языковым свидетельствам. Авторитетный для них топос западной патристики ничего не говорил о природе иврита, признавая его священным в силу причастности этого языка к библейской истории: ставший «телом» Ветхого Завета, он считался родным для Адама, патриархов, пророков и, наконец, Спасителя [4. С. 792]. При этом в известном стихе Вульгаты: Appellavitque Adam nominibus suis (выделено мною. - A.K.) cuncta animantia... (И нарек Адам всех животных их [собственными] именами) (Gen 2:20) - можно было усмотреть намёк на онтоэпистемическое совершенство праязыка. Но из-за скудного знакомства с ивритом на средневековом Западе это указание, похоже, не удостаивалось серьёзной рефлексии. Зато теперь оно приобрело важнейшее значение для всех сторонников анализируемого комплекса «найти, чтобы обосновать» вне зависимости от того, какую - гебраистскую или одну из националистских форм - они развивали.

Что именно они стремились найти? Во-первых, следы Ursprache в остальных наречиях, чтобы тем самым доказать его историческое первенство. Во-вторых, факты, подтверждающие его эксклюзивное онтоэпистемическое качество, о котором, как верили многие, свидетельствовал стих Вульгаты и которое бы обнаруживало себя в фундаментальной мотивированно- 
сти значений его слов. Большинство филологов XVI-XVII вв. считало, что «изначальные корни слов [первоязыка] были образованы не по воле случая, а на основании Природы и разума» ${ }^{1}[5]$. В-третьих, часть исследователей стремилась подтвердить идею исконной односложности этих корней, являющей замечательную простоту формального устройства Ursprache. Теперь ответим на вопрос: что именно они стремились доказать таким, позитивно-наглядным, образом, сопровождавшимся опорой на известный мифоисторический нарратив? Ответ, казалось бы, очевиден: адамический статус своего кандидата. Но в отличие от ситуации, характерной для стратегии I, понятие адамичности было менее чётким в работах, реализовывавших комплекс «найти, чтобь обосновать». Гебраистская и националистские концепции по линии Па содержали весьма разные трактовки этого понятия. Несколько упрощая картину, мы можем свести их к двум - «сильной» и «слабой» - версиям, каждая из которых строилась на своём собственном наборе идей и презумпций. В согласии с «сильной» версией иврит или язык одной из европейских наций в его современной или, чаще, древней форме считался адамическим в строгом смысле как язык Рая, не повреждённый ни грехопадением, ни Вавилонским смешением, ни какой-либо другой катастрофой или естественной мутацией. В «слабых» же версиях этой стратегии любой кандидат мог рассчитывать не на роль первозданного (как таковой Ursprache утрачен и неизвестен), а на статус его ближайшего прямого «потомка», сохранившего максимум адамических свойств. Повторяя отношение стратегии I к ІІа, «сильный» вариант последней нуждался в поддержке со стороны определённой культурной традиции и её метарассказов больше, чем «слабый». Ибо как бы ни были весомы лингвистические данные, приводимые в доказательство адамичности того или иного наречия, их в принципе не могло быть достаточно для решения этой задачи. Поскольку цель «слабых» версий была скромнее, то и значимость идеологической составляющей в них была не такой высокой.

\section{Проблема адамичности иврита в гебраизме}

Войдя в детали гебраистской формы стратегии IІа, мы обнаружим, что приверженцы её «сильной» версии расходились в том, какой именно иврит считать адамическим, не говоря уже о точном значении этого предиката. С одной стороны, были те, кто считал первозданным иврит вообще. Они верили, что этот язык сохранялся не затронутым Вавилонским смешением в роду праправнука Сима Евера, передаваясь «Аврааму, Моисею, Судьям, великой синагоге раввинов, ко Христу и вплоть до настоящего времени» ${ }^{2}$ [6. Р. 194]. Это воззрение объединяло таких несходных деятелей, как иезуит Афа-

1 «...Patet Primigenias Vocum Radices non fortuito, sed ex Naturae \& rationis fundo enatas». Здесь и далее, где в ссылках при цитатах нет номера страницы, в данной части оригинального текста (как правило, это предисловие) отсутствует пагинация. Перевод всех цитат выполнен мною. В сносках к ним приводится оригинал.

${ }^{2}$ «[Illa... integra tamen in domo Heber] usque ad Abraham,Moysen,Judices \&c.in synagoga magna Rabbinornm usque ad Christum». 
насий Кирхер, протестантские учёные Иоганн Буксторф и Николас Фуллер, часть идеологов радикальных сект в Англии. Широтой своего гебраизма они были обязаны разным причинам: сектанты - поверхностному знакомству с ивритом и до некоторой степени симпатии к Каббале, Кирхер - той же симпатии, но, главное, согласию с мнением латинских Отцов, которое разделяли и упомянутые протестантские интеллектуалы. С другой стороны, были те, кто признавал адамическим язык Ветхого Завета, считая, что эта Книга единственно написана на чистом иврите. «Прочие же тексты, созданные посредством той же графики, либо являются халдейскими, либо содержат примеси других диалектов и [инородных] слов» ${ }^{1}$ [7. Р. 47]. Приверженцы этой позиции - к ним относились протестантские филологи Теодор Библиандер, Георг Филипп Харсдорфер, Брайан Уальтон и т.д. - считали, что, подобно всем прочим наречиям, иврит терял со временем свою исходную форму, однако эти изменения начались в нём после создания Ветхого Завета. В силу этого язык Писания был также языком Рая и первых поколений людей до Вавилонской катастрофы. И он, по словам цюрихского эрудита Библиандера (1505-1564), будет вновь дарован всем спасённым в Царствии Бога [8. P. 37-38].

Создатели «слабой» версии гебраизма находили иврит исторически первым, но не адамическим языком в строгом смысле. С их точки зрения, Ursprache стал изменяться с начала земной истории, произведённого грехопадением. По этой причине к моменту Вавилонских событий он был единственным, но не первозданным языком человечества. Об этом, в частности, писал Клод Дюре, французский лингвист и ботаник (ок. 1570-1611), в своей монументальной Сокровищнище истории языков этого мира (Thrésor de l'histoire des langues de cet univers) (1613). К такому же мнению склонялся Конрад Гесснер, автор лингвистической энциклопедии Митриdam (Mithridates) (1555). В этом труде Гесснер обходится почти без ссылок на мифоисторию, введённую в оборот Августином и Иеронимом. При этом сам иврит он характеризует как «первый», «древнейший», «чистый» от заимствований и «священный» в том смысле, что это язык Писания [7. Р. 2-3, 47]. Названные атрибуты ничего не говорят о его неизменяемости на этапе между началом истории и созданием библейских текстов.

Пути обоснования прав иврита в обеих версиях имели больше сходств, чем различий. Помимо обязательной опоры на известный мифоисторический нарратив, «сильный» вариант гебраизма обычно отличался характерным акцентом на структурной простоте этого языка. Так, Кирхер указывает на трёхбуквенный состав первоначальных корней иврита, что не свойственно прочим наречиям [6. Р. 148-149]. К иным (общим для обеих версий) доводам относилось указание на сугубо еврейский характер имён, упоминаемых в Бытии, этой древнейшей книге Библии: Адам, Ева, Каин, Ламех, Ной и т.д. [Ibid. Р. 194; 8. Р. 37]. Здесь же доказывалось то, что в

\footnotetext{
${ }^{1}$ «...Caeteri iisdem characterib. Scripti vel Chaldaici sunt, vel alias dialectos \& glossas admixtas habent».
} 
каждом существующем языке можно найти древнееврейские элементы, ибо «нет ни одного [наречия], которое бы не происходило из иврита и не содержало бы в себе его искажённых слов» ${ }^{1}$ [7. Р. 2] (см. также: [8. Р. 37; 6. Р. 194]). Кроме того, апологеты гебраизма, особенно его «сильной» версии, часто подчёркивали онтоэпистемическое совершенство этого языка, объясняя его в эзотерическом или позитивистском духе. Если Кирхер, учивший о «наполненности» иврита «сокровенными тайнами» (mysteriis confertissima), отсылает за разгадками к Каббале, то гебраисты в большинстве своём подтверждали эту идею с помощью данных этимологии. Отложив на время разговор о сущности ренессансной этимологии, ограничимся одной иллюстрацией. В «Сокровищнице» Дюре древнееврейское название орла nesher возводится к глаголам shor (cмотреть) и iashar (быmь пряMblм), в чём якобы сокрыт удивительный факт орнитологии: эту гордую птицу отличает от прочих пернатых прямота зрения [9. Р. 39-40]. Эта и подобные ей этимологические находки, которыми пестрят работы гебраистов и сторонников националистских форм, проясняют то, почему уверенность в фундаментальной мотивированности Ursprache или первого его отпрыска удобно сочеталась с представлением об односложности их исконных слов. Разложение на формально-семантические атомы позволяло «подбирать» мотивировку, казавшуюся удачной в той мере, которая оправдывала смысл библейского стиха: «И нарек Адам всех животных их именами».

\section{Образ построения националистских теорй}

Подъём националистских форм, в которых осуществлялась стратегия ІІа, и в частности комплекс «найти, чтобы обосновать», был обусловлен рядом факторов. К ним относился кризис гебраизма, вызванный прогрессом историко-филологических штудий в этой области, и рост национального самосознания у западных интеллектуалов. Они питали живой интерес к прошлому своих народов, стремясь доказать их древность, благородство и особую важность их исторических судеб. Благодаря усилиям этих учёных стал переосмысляться культурно-исторический статус европейских языков. Обретавшие литературную форму, подвергавшиеся первым опытам нормализации, они становились объектом, достойным научного исследования и художественной культивации. Арсенал средств, созданный гуманизмом в сфере классической филологии, теперь переносился в эту новую область. Такая работа была тем более актуальной, что возрождение классической, заведомо мёртвой латыни делало этот язык всё менее пригодным для коммуникации, что повышало ценность народных наречий.

Среди многообразных националистских форм самыми востребованными были скифская, тевтонская и кельтская. При этом часто кельтская объ-

\footnotetext{
${ }^{1} \ll \ldots$ Nulla enim est quae non a Hebraica deriuata quaedam \& corrupta uocabula habeat».
} 
единялась с одной из двух первых, образуя скифо-кельтскую и кельтогерманскую формы [10. Р. 895; 11. Р. 52-53]. Как в случае с гебраизмом, они тяготели к разделению на «сильные» и «слабые» версии. В зависимости от этого находилась степень важности для них тех мифоисторических нарративов, которые их фундировали, и - чего не было в гебраизме - coдержание этих метарассказов. Поскольку последние являлись идеологическим «новоделом» (никогда прежде никому бы и на ум не пришло обосновывать адамичность народных наречий), их потенциал - особенно в «сильных» версиях - был слишком мал для того, чтобы стяжать широкое признание. Поэтому в националистских формах поиск лингвистических доказательств играл гораздо бо́льшую роль, чем в гебраизме. И прежде чем разбирать аргумент от языка, окинем взором эти обосновывающие нарративы.

Повествования, служившие опорой ключевых националистских форм, имели общее ядро. Его составляла история ветхозаветных патриархов (Быт. 4-11), дополненная сведениями из «Иудейских Древностей» Иосифа Флавия, фрагментов трактата Псевдо-Берозия, сфабрикованного Аннием из Витербо (ок. 1432-1502) ${ }^{1}$, «Германии» Тацита и иных источников. Согласно легенде, созданной творцами скифской формы (Беканом, Клювером, Штирнхильмом и т.д.), когда окончился Потоп, Ной с домочадцами и прочим содержимым его Ковчега высадился на берегах Скифии, занимавшей районы Северного и Восточного Причерноморья. Спустя некоторое время отпрыски библейского патриарха стали рассеиваться по свету, мигрируя преимущественно в южном направлении. Сойдясь в земле Сенаар, они задумали воздвигнуть Вавилонскую башню (Быт. 11). В то же время семья Гомера, происходившего от Иафета, старшего сына Ноя, устремилась на север Европы, что помешало ей принять участие в легендарной стройке. Благодаря этому она не испытала на себе трагических последствий Вавилонской катастрофы. Тогда как наречия других родов изменились до неузнаваемости, повергнув человечество в неудобное положение языкового многообразия, язык гомерийцев (они же кимвры и киммерийцы) единственно сохранил допотопную, первозданную форму [12. Р. 204, 213, 534; 13. Р. 25, 204]. В силу продолжительной изолированности североевропейских народов в их языках она осталась относительно неповреждённой [14. Р. 36-37; 15. Р. 108-109, 306-309]. Далее приверженцы скифской и скифо-кельтской линий дискутировали о том, в каком современном языке: бельгийском, шведском, нидерландском и т.д. - эта киммерийская форма сохранилась в наиболее чистом виде.

Адвокаты тевтонской и кельто-германской линий начинали повествование с той же цепи библейских патриархов, но, не останавливаясь на Гомере, шли к сыну его Аскеназу, которого делали отцом Туиско - героя, отсутствующего в Писании. Этот мифический персонаж был заимствован

\footnotetext{
${ }^{1}$ Commentaria super opera diversorum auctorum de antiquitatibus loquentium. Roma, 1498. Характеристику труда Анния см.: [11. Р. 49-54].
} 
из указанных трудов Псевдо-Берозия и Тацита [16. С. 354; 17. Р. 9]. Именно он, Туиско, стал «отцом германцев и сарматов» (Псевдо-Берозий), приведшим эти народы в земли их настоящего жительства. Впрочем, некоторые утверждали на эту роль Аскеназа, избегая возвышения языческого героя [10. Р. 892]. Согласно «слабой» версии адамизма, доминировавшей во всех националистских формах, сей прародитель, кого бы им ни признавали в действительности, вывел германцев из Азии, где наряду с другими народами они стали жертвами Вавилонской катастрофы. По «сильной» же версии, намеченной у баварского историка Авентина (1477-1534), Туиско повёл своих соплеменников непосредственно из Армении, где, на взгляд многих, обитали первые послепотопные поколения [17. Р. 9]. Впоследствии этот вождь был воспринят германцами в роли их родового бога, и в честь него они стали называть себя тевтонами - «Teutsch» или «Deutsch» [16. С. 354; 18. Р. 7-8].

Эти мифоисторические схемы варьировались в деталях, отдельные из которых будут затронуты далее. Переходя к анализу ренессансной этимологии - главному методу построения лингвистических доказательств в рамках стратегии ІІа, отмечу, что независимо от того, в каких формах и версиях этой стратегии она применялась, её принцип действия был единым. В отношении языка-претендента он состоял в нахождении «истинной» мотивировки его лексических значений, призванной подтвердить фундаментальное соответствие адамических слов природе вещей. Относительно прочих, «позднейших», наречий он сводился к отысканию в них адамических элементов. Когда эти процедуры соединялись, их общей целью становился поиск в существующих языках таких слов, чья семантика, будучи истолкованной в терминах языка-претендента, являла бы неким достаточно ясным образом свою мотивированность, а та - их солидный эпистемический потенциал. Обратимся за примером к Горопию Бекану (1519-1572), нидерландскому учёному, ставшему притчей во языцех из-за своей теории, по которой Ursprache вполне сохранился в брабантских диалектах фламандского языка. Желая доказать исконно фламандский характер слова «Адам», якобы унаследованного ивритом, Бекан раздробляет имя праотца на два этимона: hat и dam. В его родном наречии они означали ненависть и дамбу соответственно. Прочитывая их вместе как дамба для потоков ненависти, наш этимолог усматривал в сей фразе полное глубокого смысла знамение, о котором вовсе не подозревали иудеи: «Это было наилучшее увещание для Адама, [заключённое в самом] его имени, чтобы он твёрдо противостоял ненависти змия, подобно дамбе, о которую сокрушаются волны океана» ${ }^{1}$ [12. Р. 539].

Оставив ненадолго Бекана, коснёмся системы презумпций, лежавшей в основании столь странного, на сегодняшний взгляд, этимологического анализа. Её главными элементами являлись кратилизм и вера в превосход-

\footnotetext{
${ }^{1}$ «Optima haec fuit Adamo de nomine suo admonitio, quo fortiter inuidiae serpentis resisteret, non aliter, quam agget Oceani fluctibus perpetuo verberandus...».
} 
ство «древней мудрости» (prisca sapientia). Под кратилизмом подразумевается убеждение, что между словом и означаемым существует исконная органическая связь. Чаще всего она теряется в процессе изменения языка, однако может быть воссоздана с помощью этимологии [19. Р. 97]. Предельная цель последней заключалась в том, чтобы путём подчищающих подтасовок, основанных на произвольных ассоциациях звуков, идей и понятий, отыскать в каждой лексеме её изначальную форму - «колыбель» слова (cunabulum verbi), по образному выражению стоиков. Отличительная черта этой формы - её звуковое соответствие означаемой вещи. Благодаря ему искомая форма должна быть настолько очевидной для разума, что всякий наделённый живым умом мог без всяких разысканий постигать через неё значение слова, прямо указывающее на его референт. Были известны два типа акустического иконизма: подражательный и символический. Согласно первому в звуковом образе слова воспроизводилось реальное звучание вещи, а согласно второму, этот образ служил акустическим отражением общего психологического действия, производимого вещью на человека (ср. латинское mel, означающее мёд, или сrux - крест) [20. С. 77-78]. Оба этих типа и связанные с ними эвристические приёмы, входившие в состав этимологического метода, сохраняли силу до тех пор, пока оставался актуальным адамический проект.

Вместе с тем raison d'etre этого метода не сводился к обнаружению акустического согласия между словом и вещью. Как заметил ещё Августин, критикуя стоическую этимологию, нахождение правдоподобной «колыбели» случается очень редко [Там же. С. 78]. В большинстве случаев, вопреки надежде и усилиям толкователей, звуковой образ слова оставался слишком тёмен для того, чтобы сквозь него могла проступить сущность именуемой вещи. Кроме того, этот подход мог применяться лишь к первообразным единицам, тогда как основной массив любой лексики характеризуется производностью. В таких случаях тоже можно было апеллировать к этимологии - но не с целью поиска исходного звучания слова, а ради выявления присущей ему внутренней формы. Ибо считалось, что между морфологосемантическим устройством слова и структурой свойств предмета может существовать изоморфизм (опять же буквальный или символический), позволяющий через анализ имени раскрыть существо именуемого. Богатая объяснительными возможностями, эта грань этимологических спекуляций была более всего востребована теми, кто действовал внутри комплекса «найти, чтобы обосновать». Примером нахождения буквального изоморфизма может стать уже известный нам анализ древнееврейского названия орла, предложенный Клодом Дюре, а иллюстрацией символического изоморфизма - разбор слова Адам у Горопия Бекана.

Что касается второго звена системы презумпций, фундировавшей ренессансную этимологию, - убеждения в превосходстве «древней мудрости», - эта вера была неотделимой от коренной установки гуманизма, звучавшей в призыве ad fontes! (к истокам). Она вызвала к жизни воззрение, по которому чем более древним и, соответственно, близким к Ursprache 
является то или иное наречие, тем более глубокие истины в нём сокрыты. Так что каждый, кто стремился обосновать исключительный статус своего языка-кандидата, ориентировался не просто на то, чтобы найти в лексиконе его конкурентов элементы защищаемого наречия, а в них внутреннюю форму, удобно “прочитываемую” в его терминах. В идеале ученый должен был показать, что хотя бы часть этих элементов содержит в себе фундаментальные положения религиозно-метафизического (ср. Беканову трактовку имени праотца) или естественно-научного порядка (ср. орнитологический тезис Дюре).

Завершая очерк этимологического метода, отмечу, что до конца XVII в. он не претерпел существенной трансформации. Его базовые принципы оставались теми же, как они были сформулированы в Античности: в «Кратиле» Платона, у стоиков и в концепции претерпевания александрийских грамматиков [21. Р. 47-94]. Изменением, ознаменовавшим начало Модерна, стал рост недоверия к этимологии как методу миропознания. Иными словами, интеллектуалы постепенно разочаровывались в системе презумпций, утверждавшей наличие органичной связи между знаком и означаемым, а также таинственной метафизики и науки, зашифрованных в первословах [19. Р.97]. В отношении самой техники и приёмов этимологии остаётся верным замечание Ханса Аарслеффа: на протяжении XVII в. было обычным делом применять эту технику не для поиска новых знаний, но чтобы подвести под некий априорный постулат лингвистическое основание [22. Р. 91]. Это обстоятельство проливает дополнительный свет на причины той могучей притягательности, которой обладала этимология в умах всех адептов стратегии ІІа. Оно же объясняет существенное различие между ренессансной и современной, собственно научной, версиями этимологии. В отличие от последней, гуманистический анализ происхождения слов строился без учёта законов фонетических изменений, представлявшихся алогичными, морфологических закономерностей и многих проявлений грамматической системности. По этой причине его творцы во многом полагались на свою интуицию, сближая этимологию с искусством. Отсутствие строгих методологических правил минимизировало возможность «отсеивать» случайные сходства между словами и открывало простор для псевдообъективных утверждений и тенденциозных выводов.

\section{«Сильная» версия национализма: Горопий Бекан}

В своём большинстве националистские теории адамизма относились к «слабому» типу. Их авторы искали такие свидетельства, которые подтверждали бы максимальную генеалогическую близость своего кандидата к Ursprache. Всерьёз утверждавших, что их претендент - это в точности язык Рая и самых первых человеческих поколений, не могло быть много в период усиления скептико-критического духа, который сопровождал подъём новоевропейского рационализма. К числу этих немногих относились среди прочих Марк Цуэрий Ван Боксхорн, Иоганн Магнус и не раз упоминав- 
шийся Горопий Бекан. Взяв за образец «сильной» версии теорию Бекана, рассмотрим этимологические построения этого гуманиста, в которых он создал свой многосторонний аргумент от языка ${ }^{1}$.

Когда филологи-адамисты всевозможных националистских толков желали найти повсеместные следы своего кандидата, они незамедлительно обращались к языкам-конкурентам и прежде всего к ивриту. Эти учёные считали (и в условиях господства моногенетического принципа правильность данного допущения чаще всего не подвергалась сомнению), что, победив конкурентов, они тем самым доказывали наличие таких следов во всех языках человечества. Так поступал и Бекан. Существенная часть этимологических выкладок, представленных в его главном труде Антверпенские древности (Origines antwerpianae) (1569), направлена на то, чтобы реконструировать «исконные»киммерийские - основы в латинском, древнегреческом и, главное, древнееврейском языках [12. Р. 32-33, 847-848]. Вступив в борьбу с гебраистами на лингвистическом поле, он пытался выхватить из их рук и обратить против соперников их же оружие. Гебраисты и в особенности знатоки Каббалы апеллировали к уникальной древности Моисеева Пятикнижия. Бекан, со своей стороны, доказывал, что Тора древнее, чем те думают, и Моисей был не автором её, а транслятором, принявшим этот текст переведённым на иврит с «первозданного» языка киммерийцев [Ibid. Р. 537].

Когда гебраисты указывали на библейские имена и названия, не поддающиеся переводу и имеющие древнееврейское происхождение, Бекан парировал: эти имена действительно изначальны и, как все адамические слова, глубоко мотивированны, но они имеют лишь видимость древнееврейских. Дело в том, что потомки Ноя сберегали их в своих поствавилонских наречиях, удерживая в памяти их начальные смыслы. Так, возможно, по цепи языков-посредников эти слова вошли в иврит, запечатлённые в древнееврейском тексте Пятикнижия. Однако впоследствии их исконные значения забылись, а их место заняли толкования, привнесённые раввинами, ибо в отличие от Моисея они уже не имели доступа к «древней мудрости» и хранившему её языку [13. Р. 11] $]^{2}$. Так, например, имя предка Ноя Мафусаила (Methuselah) прочитывается Беканом как нидерландское maek thu salich, что переводится как «делающий себя благословенным» и в отношении этого патриарха указывает на причину его долгожительства [12. P. 548]. Имя самого Ноя разлагается на первоатомы noot (нужда) и acht (уделять внимание), указывавшие вместе на великую предусмотрительность этого патриарха [Ibid. P. 549]. А «Вавилон» (Babel) наш лингвист возводит к babelen, превращая название рокового места в памятник презрения к тем, кто отпал там от первозданного языка и, на слух его сохра-

\footnotetext{
${ }_{1}^{1}$ Детальный анализ этимологических техник Бекана см. [23].

2 Сходную мысль формулирует один из творцов «слабой» кельто-германской версии Филипп Клюверий (1580-1622), уча, что если ветхозаветные имена действительно древнееврейские, то либо они сохранились в иврите как следы утраченного Ursprache, либо евреи перевели их с более древнего языка [24. Р. 74].
} 
нивших, стал «бормотать, говорить бессмыслицу» [Ibid. P. 572; 13. Р. 218].

Будучи чрезвычайно изобретательным этимологом, наделённым богатым воображением, Бекан не всегда довольствовался одним значением препарируемого слова. Когда выпадал подходящий случай, он охотно пускался в хитроумные герменевтические спекуляции, артистически играя прихотливыми смысловыми ассоциациями. Так что нередко фундаментальная мотивированность слов киммерийского языка, над воссозданием которого он трудился, под его пером достигала семантической многослойности. И это было не просто следствием живой страсти Бекана к аллегорическому этимологизированию, ещё не скованному методологическими правилами, необходимость которых стала осознаваться филологами в следующем столетии [14. Р. 44]. Уникальная глубина означаемого постулировалась им в качестве характерной черты Ursprache. Она отличала его от позднейших наречий и обеспечивалась изначальной односложностью киммерийского языка, чьи слова превосходно объединялись в сложные лексические единицы [13. Р. 25]. Продолжая творить язык, Адам создавал многие имена таким образом, что они представляли собой своеобразную тайнопись, скрывавшую «тайны древней Теологии» [12]. Тайны эти были столь велики и обильны, что «в целом мире [земных] наук до сих пор не нашлось ничего сопоставимого с ними» [Ibid. P. 539].

Заключая анализ адамических спекуляций Горопия Бекана, отмечу, что возможность, которую он воплотил, отстаивая перед лицом «республики учёных» раздутое величие своего языка, оказалась предельной в отношении вмещавшей её системы презумпций. По этой причине отдельные постулаты нидерландского гуманиста находились на грани абсурда. Не желая того, Бекан «нащупал» пределы этой системы и приблизил этим час её демонтажа, пробивший в середине XVII столетия. Положив начало националистическому течению внутри адамического проекта, он открыл врата другим претендентам на роль первозданного или ближайшего к нему языка [25. Р. 21, 69]. Сделалось ясно, что примерно с тем же успехом, который снискал Бекан, теперь можно было обосновать первозданность любого наречия. Так была дискредитирована идея, что Ursprache мог сохраниться после Вавилонского и дальнейших, естественных, трансформаций исторических языков. Это обстоятельство повышало популярность «слабых» националистских версий, к обсуждению которых мы переходим.

\section{Система «слабых» националистских форм}

В основе «слабых» версий всех националистских форм лежало убеждение в том, что как таковой язык Адама невозвратимо утрачен и неизвестен. При этом мера его неизвестности различествовала в пределах между условным ивритом, генетически родственным, но не тождественным языку Писания, и полным неведением. Забвение Ursprache объяснялось одним из двух способов, имевших подтверждение в Библии. Прибегавшие к перво- 
му - сам этот способ можно назвать естественным, а его сторонников эволюционистами - апеллировали к десятой главе Бытия, предшествующей той, где идёт речь о Вавилонском столпотворении. В ней излагается послепотопное «родословие сынов Ноевых... по племенам их, по языкам их, в землях их» $(\mathrm{X})$. Отсутствие указаний на какие бы то ни было чудесные события внушает мысль о естественном характере происходившей дифференциации, что как будто противоречит сюжету о злополучной Башне, идущему вслед за этим родословием (XI:1-9). История о Вавилонском смешении была отправной точкой для тех, кто объяснял возникновение многоязычья вторым - катастрофическим - способом.

Позиция эволюционистов не была монолитной. Одна их часть развивала мысль об изменении первозданного языка, параллельно протекавшем несколькими путями. На их взгляд, первоязык изменился сразу в две или более исторические формы, связанные между собой единством истока. Как правило, в качестве таких форм постулировались иврит и материнский язык учёного, превозносившего его древность. Другое крыло эволюционистов защищало представление о последовательной мутации Ursprache, в силу которой тот сначала изменился в их кандидата (если для националиста это был чаще всего родной язык, то для приверженца «слабой» версии гебраизма - исторический иврит). Затем от ближайшего отпрыска отделилось следующее и шаг за шагом все позднейшие наречия. В этом плане показателен образ лингвоисторического мышления выдающегося шведского учёного Георга Штирнхильма (1598-1672). В своих ранних трудах он утверждал идею параллельной трансформации, считая первыми наследниками Ursprache иврит и готский, он же скифский, язык, в наиболее чистом виде сохранившийся в шведском. Однако позднее этот лингвист встал на позицию последовательного изменения, поставив иврит, наряду с другими наречиями, в зависимость от готского [15. Р. 307-308; 26. Р. 164].

В течение XVII в. влияние эволюционизма росло, стимулируемое тем, что сравнительно-историческое изучение языков становилось самоценной научной областью, независимой от теологии. К числу виднейших эволюционистов принадлежали Адриан ван Шкрик, Абраам Милий, Жан де Лайет, Андреас Йегер и др. Вместе с тем на протяжении интересующей нас эпохи традиционная теория катастрофизма, похоже, казалась убедительной большинству учёных. Считая смешение в Вавилоне причиной возникновения всех исторических языков, катастрофисты вели споры о том, как в точности возникли те 72 (или около того) языка, которыми, по шедшей из Средневековья традиции, исчерпывалось лингвистическое многообразие мира. На взгляд одних, по-своему принимавших эволюционистский принцип, все языки возникли из нескольких диалектов (matrices), в которых Бог «растворил» Ursprache. Другие верили в их обоюдно независимое появление, постепенное и различное по темпу или мгновенное и, стало быть, од- 
новременное $^{1}$. Интересно, что защитники симультанного сценария часто полностью меняли тональность Вавилонской катастрофы, толкуя её в сугубо позитивном ключе, гармонировавшем с духом национализма. В этом новом позитивном свете она осмыслялась следующим образом: создав множество языков, Бог не столько покарал человечество неудобным для него разноречием, сколько одарил его богатством наречий, которые - в силу их божественного установления - тоже обладали атрибутами совершенства, пусть и в меньшей степени, чем первоязык, бледные подобия которого они представляли [11. Р. 45, 58]. Вместе с тем, в целом исторический процесс языковых изменений казался катастрофистам, равно как и всем апологетам стратегии ІІа, по преимуществу деструктивным. Они видели в нём деградацию, уводившую языки от состояния начального совершенства [18. Р. 152; 14. Р. 24]. Её главными механизмами считались диверсификация, происходившая за счёт разудаления племён, чей язык был един вначале, и смешение наречий в результате чрезмерных заимствований. Причины заимствований, называемые в то время, до сих пор представляются состоятельными. В качестве основных считали политические (геноцид, утрата суверенитета и т.д.) и миграционные (слияния народов в эпохи великих переселений и т.п.) факторы [6. Р. 130-131; 7. Р. 2-3]. К ним добавляли появление в обиходе новых вещей, перенятых вместе с названиями, а также усвоение иноземных искусств и ремёсел с присущим им багажом профессионализмов [7. Р. 3].

Итак, каким бы - естественным или чудесным - ни было возникновение разноязычья, оно дало ход последующей мутации, естественный характер которой признавали все филологи XVI-XVII вв. Вместе с тем эти учёные считали, что темп и сила исторических изменений различались в отношении конкретных семей языков и отдельных наречий. Помещённые в ретроспективу, существующие языки представлялись им по-разному удалёнными от адамического или, в случае катастрофистов, вавилонского первоистока. Говоря более точно, все работавшие в рамках комплекса «найти, чтобы обосновать» проводили различие между одной (и реже двумя или несколькими) языковой семьей или языком и остальными наречиями. Эта привилегированная группа или язык составляли исключение из правила универсальной мутации. Суть их особенности известна нам из мифоисторических нарративов, созданных для её подтверждения. Она состояла в том, что из-за долгой, беспримерно долгой территориальной и культурной изоляции, которой неким случайным или промыслительным образом подвергся данный народ, его языку посчастливилось сохранить в наиболее чистом виде свою первозданную форму, будь то эдемский (в «сильных» версиях) или один из вавилонских праязыков (в «слабых» версиях ката-

\footnotetext{
${ }^{1} \mathrm{Cp}$. утверждение Клюверия: «Никто не мог бы с лёгкостью опровергнуть то, что все языки произошли одновременно из одного источника и одного и того же корня» ( $\mathrm{Ab}$ una origine, unaque et eadem stirpe omnes pariter in universum promanasse orbem terrarum linguas, nemo facile negaverit) [24. P. 38].
} 
строфистов). Интеллектуальный спрос на такие концепции длительной автономии был весьма высок в ренессансной Европе, и мы знаем его мотивы. Нам также известно, как выстраивалась лингвистическая грань этих концепций в трудах гебраистов и адвокатов «сильных» националистских вариантов. Пришло время рассмотреть нюансы этимологической работы в «слабых» формах национализма, наиболее специфичными из которых были концепции симультанного катастрофизма, развитые Полем Пезроном, Филиппом Клюверием, Ричардом Верстеганом и др. Обратимся для этого к построениям Верстегана, посвящённым доказательству сугубой древности английского языка.

\section{Концепция Ричарда Верстегана}

Британский историк, писатель, гравер и издатель Ричард Верстеган (ок. 1550-1640) был в первую очередь стойким католическим апологетом. По этой причине его opus magnum Восстановление расстроенного разумения древностей (A Restitution of Decayed Intelligence in Antiquities) (1605) вместе с видимостью сугубо академического трактата имел идеологическую цель. Она состояла в том, чтобы развенчать миф об извечной культурно-религиозной независимости Британии, избегая прямой полемики с его творцами - протестантскими пропагандистами времён Тюдоров. Вдохновляемый этим замыслом, Верстеган стремился продемонстрировать с как можно большей убедительностью общегерманскую, или тевтонскою, основу английского языка и культуры, всё ещё явственно в них прослеживавшуюся, и, соответственно, их древнюю связь с католичеством. Надо заметить, это стремление хорошо сочеталось с его взглядом на адамическую проблему. Автор «Восстановления» относился к тем представителям катастрофизма, для которых «смешение» в Вавилоне означало появление новых наречий, не лишённых - коль скоро они созданы Богом ${ }^{1}-$ значительной степени совершенства. К числу сих первых (после эдемского) языков принадлежал тевтонский. Общий для всех германцев, он обладал достоинствами, сближавшими его с Ursprache. Разделяя участь всех наречий, этот язык дробился и изменялся по мере того, как говорившие на нём племена всё сильнее отмежёвывались друг от друга и вступали в контакт с иноземцами. Только саксонцы, удалившись из Германии на Британские острова, где пребывали в относительной изоляции, долгое время хранили Teutonick tongue в наиболее чистом виде [18]. Поэтому, несмотря на позднейшие вливания извне и возникшую порчу, он - при должном этимологическом мастерстве исследователя - до сих пор предлагает удобный доступ к своему вавилонскому корню.

Техника лингвистического доказательства, заметная в «Восстановлении», мало отличается от той, которой пользовались прочие творцы стра-

\footnotetext{
${ }^{1}$ Верстеган именует Бога «их Автором и Основателем» (the Author and Founder thereof) [18. P. 192].
} 
тегии ІІа, и в частности «сильных» националистских форм. В этом плане Верстеган шёл по пути Бекана и его последователей - с оговоркой, что культурная относительность, вытекавшая из симультанного катастрофизма, не позволяла нашему англичанину заходить так же далеко в его выводах. В противоположность Бекану, он не покушался на то, чтобы перераспределить старшинство между древнееврейским и тевтонским языками, признавая, что на стороне иврита стоит древняя церковная традиция. Не подвергая её явному сомнению, Верстеган концентрировался на сравнении адамических свойств тевтонского и его конкурентов. Согласно его наблюдениям язык древних германцев ничуть не уступает ивриту и превосходит некоторые из классических языков [Ibid. P. 150, 192]. Чтобы дать обоснование своему тезису, он ненадолго предаётся компаративистскому состязанию, излюбленному нидерландским предшественником. Так, он показывает, что библейские имена, уже изрядно затасканные этимологами, обнаруживают самую уместную и многозначительную внутреннюю форму, когда прочитываются именно по-германски, а не по-еврейски или поскифски. Например, выясняется, что «Адам на этом языке означает живое дыхание», и это в точности соответствует библейскому пассажу о сотворении человека (Быт. 2:7), что Ева (Eve) образовано от равный, одинаковый по достоинству (even), а Каин (Kain) происходит от гневный и жестокий (quain), что проявилось в обращении с братом» и т.д. [Ibid. P. 149].

Эта тяжба с гебраистами и защитниками прочих националистских форм не была столь увлекательной для Верстегана, чтобы часто отвлекать его от собственно германского материала. Как лингвист он был занят в основном этимологией тевтонских слов, без оглядки на языки-конкуренты. Исходя из известных нам принципов кратилизма и примата «древней мудрости», Верстеган утверждал, что фундаментальная мотивированность служит «превосходным знаком величайшей древности» германского языка. На его взгляд, именно это свойство лучшим образом сближало язык тевтонцев с Ursprache, который - из-за уникального его соответствия миру - автор «Восстановления» именует «природным» [Ibid. P. 4]. Впрочем, порой, когда появлялась удобная возможность, Верстеган предлагал читателям сравнить удачно мотивированное англо-тевтонское слово с очевидно произвольным эквивалентом из латыни или иного классического языка (ср.: God (Бог) от good (благой) в английском против не связанных друг с другом Deus и bonus в латыни; woman (женщина) из слияния womb-man (человек с маткой) против латинского hото, никак не выражающего половое различие людей) [Ibid. P. 150-151]. Подобно некоторым филологамнационалистам: Бекану, Штевину, Клюверию и проч., - Верстеган видел ещё один признак совершенства тевтонского в постулируемой им начальной односложности этого языка. С его точки зрения, эта черта свидетельствовала не только о первичной простоте древнегерманских слов, но и об их тотальной мотивированности. Каждое такое слово имело своё, органически соответствующее ему значение, которое усваивалось восприемниками этого языка «силой божественного и природного инстинкта», в чём чувствуется 
отзвук стоической идеи звукового символизма [18. Р. 148]. Эта исходная односложность позволила германцам в дальнейшем создавать композитные единицы, благодаря чему язык их был богат, пластичен и, главное, многозначителен, поскольку в своём большинстве его слова отличались двухуровневой - звуковой и морфологической - мотивированностью.

Уважительно относясь к Горопию Бекану, чьи этимологические приёмы он использовал, Верстеган критиковал его и других сторонников «сильного» национализма по двум причинам. Английского учёного не устраивала чрезмерная категоричность их ключевых утверждений, которой не соответствовала сила их лингвистических доказательств, тщетно компенсировавшаяся мифоисторическим нарративом [Ibid. P. 149]. Он также порицал их работы за узость эмпирической базы, которая, на его взгляд, не позволяла судить ни за ни против исторического первенства, тем паче адамичности их языков-претендентов. Увлёкшись конкуренцией с гебраистами, Бекан пренебрёг необходимым в таких случаях систематическим сравнением своего претендента с кругом родственных ему языков. Сам Верстеган подчёркивал важность сопоставительного изучения лексиконов всех германских наречий, чтобы выделить общие, исконно тевтонские элементы [Ibid. P. 154]. И в научном плане это был шаг вперёд по сравнению с тем, что делал его нидерландский предшественник, предпочитавший медитировать над метафизическими «безднами» материнского языка.

\section{Заключение}

Завершая исследование, приведём в систему то обилие форм, в которых осуществлялся комплекс «найти, чтобы обосновать» и, в его составе, рассмотренная линия второй адамической стратегии. В согласии с этой линией путь, который обещал приблизить к тайне Ursprache, шёл от известных, живых и классических, языков. Считалось, что в них таятся следы первозданного языка, сокрытые под покровом исторических изменений. Они могут быть распознаны, так как, к счастью для смертных, сохранилось такое наречие, адвокаты которого видели в нём ближайший отпрыск Ursprache («слабая» версия) и, реже, собственно первоязык («сильная» версия стратегии IІа). В силу того, что ни уникальность его природы, ни место среди других языков не были очевидны, сторонники этого претендента включали его в сравнительно-историческое состязание с другими наречиями, имевшее идеологическую подоплёку. Смотря по тому, какой язык (или языковая группа) избирался на роль претендента, все формы обеих версий делились на гебраистскую и ряд националистских вариантов, самыми востребованными из которых были скифский, тевтонский и кельтский, причём кельтский чаще всего соединялся с первым или вторым. Кроме того, все «слабые» националистские формы дифференцировались на том основании, какой сценарий возникновения и развития многоязычия в них подразумевался. С одной стороны, имелось крыло эволюционизма, включавшего параллельный и последовательный подвиды, с другой - кры- 
ло катастрофизма, тоже имевшего параллельную (как правило, симультанную) и последовательно-параллельную разновидности.

Выяснилось, что в каждой из этих форм реализация данного комплекса имела свою специфику. Говоря общо, в одних преобладал акцент на «найти» в других - на «обосновать». Но ключевые принципы нахождения / обоснования были всегда едины. К ним относилась апелляция к авторитету того или иного мифоисторического нарратива, который часто создавался ad hoc, чтобы особым образом дополнить и истолковать известные сюжеты Библии, как-то: грехопадение, Потоп и Вавилонское смешение. Причём относительно роли такой апелляции в общей структуре обоснования была замечена следующая градация: наиболее значимой опора на мифоисторический нарратив являлась в «сильной» гебраистской теории. Затем шли «слабая» гебраистская и «сильные» националистские формы, а завершали ряд концепции «слабого» национализма. В свою очередь, роль аргумента от языка была обратно пропорциональна важности этой опоры, возрастая на пути от «сильного» гебраизма к «слабому» национализму.

На протяжении XVII в. европейская компаративистика медленно освобождалась от обусловленности теологией и всей «системой координат» ренессансного мышления. Приобретали влиятельность концепции, которые, говоря в терминах адамического проекта, являлись всё более «слабыми». Вместе с тем в истории языкознания роль библейского нарратива не была негативной. Открывая простор для множества толкований, сюжеты Бытия питали лингвистическую мысль эпохи и ускоряли появление новых гипотез, многие из которых прокладывали путь индоевропейской теории. То, что действительно мешало прогрессу компаративистики, - это мода на концепции долгой культурной автономии, исключавшие отдельные языки из потока истории, а главное, отсутствие универсальных правил, регламентирующих исследования. Хотя рефлексия над правилами росла, между теоретическими принципами и практикой компаративистов оставался заметный зазор [14. Р. 44]. Уже был понят общий механизм языковой эволюции и осознана потребность в аналитическом охвате как можно большей части лексиконов предположительно родственных языков. Однако подлинный расцвет сравнительно-исторического метода смог произойти тогда, когда объектом изучения стали системы грамматических форм и была выявлена логика фонетических измерений, казавшихся прежде случайными.

\section{Литература}

1. Карабыков A.B. «И нарек человек имена...»: стратегии воссоздания адамического языка в культуре Ренессанса // Человек 2014. № 5. С. 114-131.

2. Van Hal T., Van Rooy R. Editors' introduction // Metcalf G.J. On Language Diversity and Relationship from Bibliander to Adelung. Amsterdam, Philadelphia : John Benjamins, 2013. P. $1-10$.

3. Карабыков A.B. Трансформация метафизики первозданного языка в ренессансном каббализме // Вопросы философии 2016. № 3. С. 186-197.

4. Августин Блаженный. О граде Божьем. Минск : Харвест ; Москва : АСТ, 2000. $1296 \mathrm{c}$. 
5. Georg Stiernhielm. Babel destructa seu runa Suethica Babel destructa, seu runa Suethica. Stockholm, 1669. 429 p.

6. Athanasius Kircher. Turris Babel, sive Archontologia. Amsterdam : Janssonio Waesbergiana, $1679.219 \mathrm{p}$.

7. Conradus Gesnerus. Mithridates. De differentiis linguarum tum veterum tum quae hodie apud diversas nationes in toto orbe terrarum in usu sunt. Tiguri : Froschoverus, 1555. $78 \mathrm{p}$.

8. Theodorus Bibliander. De ratione communi omnium linguarum et literarum commentaries. Tiguri : Froschoverus, 1548. $235 \mathrm{p}$.

9. Claude Duret. Thrésor de l'histoire des langues de cest univers, contenant les origines, beautés... décadences, mutations... et ruines des langues hébraïque, chananéenne... etc., les langues des animaux et oiseaux. Yverdon : Pyramus dé Candolle, 1619. $1030 \mathrm{p}$.

10. Van Hal T. One continent, one language? Europa Celtica and its language in Philippus Cluverius' Germania antiqua (1616) and beyond // European Review of History: Revue européenne d'histoire. 2014. № 21 (6). P. 889-907.

11. Travoni M. Western Europe // History of Linguistics. Vol. 3: Renaissance and Early Modern Linguistics. London; New York : Routledge, 2014. P. 2-108.

12. Goropius Becanus. Origines antwerpianae, sive Cimmeriorum becceselana novem libros complexa. Antwerp : Plantinus, 1569. $1058 \mathrm{p}$.

13. Goropius Becanus. Hermathena // Opera Ioan. Goropii Becani, hactenus in luce non edita. Antwerp : Plantinus, 1580. $237 \mathrm{p}$.

14. Metcalf G.J. On Language Diversity and Relationship from Bibliander to Adelung. Amsterdam, Philadelphia : John Benjamins, 2013. 181 p.

15. Considine J. Dictionaries in Early Modern Europe: Lexicography and the Making of Heritage. Cambridge et al. : Cambridge University Press, 2008. 393 p.

16. Tаџит. О происхождении германцев и местоположении Германии // Сочинения : в 2 т. Т. 1: Анналы. Малые произведения. Л. : Наука, 1969. С. 353-373.

17. Jones W.J. Images of language: six essays on German attitudes to European languages from 1500 to 1800. Amsterdam, Philadelphia : John Benjamins Publishing Co, 1999. 297 p.

18. Richard Verstegan. A Restitution of Decayed Intelligence in Antiquities. Concerning the Most Noble and Renowned English Nation. London : Newcomb, 1655. 264 p.

19. Anderson J.H. Words that matter: Linguistic perception in the English Renaissance. Stanford : Stanford University Press, 1996. 340 p.

20. Античные теории языка и стиля / под ред. О.М. Фрейденберг. СПб. : Алетейя, 1996. $362 \mathrm{c}$.

21. Del Bello D. Forgotten Paths: Etymology and the Allegorical Mindset. Washington, D.C. : Catholic University of America Press, 2007. 187 p.

22. Aarsleff H. From Locke to Saussure. Essays on the Study of Language and Intellectual History. Minneapolis : University of Minnesota Press, 1982. 422 p.

23. Naborn R.A. Becanus' Etymological Methods // Voortgang. 1995. № 15. P. 79-86.

24. Philippus Cluverius Germaniae antiquae libri tres. Lugduni Batavorum : Elzevirius, 1616. $400 \mathrm{p}$.

25. Burke P. Languages and Communities in Early Modern Europe. Cambridge et al. : Cambridge University Press, 2004. 210 p.

26. Simone R. The Early Modern Period // History of Linguistics. Vol. 3 Renaissance and Early Modern Linguistics. London ; New York : Routledge, 2014. P. 149-236.

The Adamic Language, European Nationalism, and the Rise of the Renaissance Comparativism

Vestnik Tomskogo gosudarstvennogo universiteta. Filologiya - Tomsk State University Journal of Philology. 2020. 66. 65-87. DOI: 10.17223/19986645/66/4

Anton V. Karabykov, V.I. Vernadsky Crimean Federal University (Simferopol, Russian Federation). E-mail: meavox@mail.ru 
Keywords: history of linguistic thought, theories of language origin, etymology, Cratylism, Boook of Genesis, Hebraism, Goropius Becanus, Richard Verstegan.

The study is supported by the Russian Foundation for Basic Research (RFBR), Project No. 18-011-00601 "The 'Book of Nature' in the Renaissance and Early Modern Hermeneutic Strategies".

The analysis is focused on one of the directions of the Adamic project developed in the Renaissance culture and aimed to reconstruct the primordial, or Adamic, language (Ursprache). Adamic was the primordial language belonging to the forefathers (while at least they remained in the condition of the initial perfection). The project presented a complex of ideas and views together with hermeneutic strategies they determined and was based on a specific set of beliefs, presumptions, and attitudes. The set included a humanistic aspiration for "the origins" (ad fontes), deep reverence for "the ancient wisdom" (prisca sapientia) the first people had possessed and expressed in the Ursprache, which had helped it survive in history, and faith for biblical and heathen narratives. It also included Cratylism, according to which lexical meanings (in their pristine form) sprang from the very essence of things due to the predetermined harmony between the structures of language and of the reality. The mentioned elements of the Renaissance thought formed a sort of a system of coordinates; supporters of the analysed strategy worked within it. The system directed them to study the Ursprache via finding its rudiments in known historical tongues (provided that there is a language that has preserved the maximum of the primordial properties). The article argues that, despite the rich variety of forms the strategy was implemented in, means of justification of some tongue's rights to be taken as the Adamic one or, more often, as its closest derivate were universal at large. They included recourse to a spectrum of mytho-historical narratives current in the Renaissance culture; using them, many Adamicists built new original constructs matching their ideological goals. Besides, the means supposed employment of a vast arsenal of tools of humanistic exegesis and etymology. Particular attention is paid to the Renaissance scholars' etymological practice, which was to provide them with the properly linguistic evidence of the "Adamic" rights of the languages those humanists promoted. The etymological analysis was typically reduced to searches for elements of Adamic in words of later historical languages and to demonstrations of a non-conventional, organically motivated link conjoining original words with their referents in the world. In order to make this double task easier, some etymologists resorted to fragmentation of words into phonosemantic "atoms" considering monosyllabism to be an essential feature of the primordial language.

\section{References}

1. Karabykov, A.V. (2014) "So the Man Gave Names": The Strategies of Reconstruction of the Adamic Language in Renaissance Culture. Chelovek. 5. pp. 114-131. (In Russian).

2. Van Hal, T. \& Van Rooy R. (2013) Editors' introduction. In: Metcalf, G.J. On Language Diversity and Relationship from Bibliander to Adelung. Amsterdam, Philadelphia: John Benjamins. pp. 1-10.

3. Karabykov, A.V. (2016) The Transformation of the Primordial Language Metaphysics in the Renaissance Cabbalism. Voprosy filosofii-Problems of Philosophy. 3. pp. 186-197. (In Russian).

4. Augustine of Hippo. (2000) O grade Bozh'em [The City of God]. Translated from Latin. Minsk: Kharvest, Moscow: AST.

5. Stiernhielm, G. (1669) Babel destructa seu runa Suethica Babel destructa, seu runa Suethica. Stockholm: [s.n.].

6. Kircher, A. (1679) Turris Babel, sive Archontologia. Amsterdam: Janssonio Waesbergiana. 
7. Gesnerus, C. (1555) Mithridates. De differentiis linguarum tum veterum tum quae hodie apud diversas nationes in toto orbe terrarum in usu sunt. Tiguri: Froschoverus.

8. Bibliander, T. (1548) De ratione communi omnium linguarum et literarum commentaries. Tiguri: Froschoverus.

9. Duret, C. (1619) Thrésor de l'histoire des langues de cest univers, contenant les origines, beautés... décadences, mutations... et ruines des langues hébraïque, chananéenne... etc., les langues des animaux et oiseaux. Yverdon: Pyramus dé Candolle.

10. Van Hal, T. (2014) One continent, one language? Europa Celtica and its language in Philippus Cluverius' Germania antiqua (1616) and beyond. European Review of History: Revue européenne d'histoire. 21(6). pp. 889-907.

11. Travoni, M. (2014) Western Europe. In: Lepschy G. (ed.) History of Linguistics. Volume III. London, New York: Routledge. pp. 2-108.

12. Becanus, G. (1569) Origines antwerpianae, sive Cimmeriorum becceselana novem libros complexa. Antwerp: Plantinus.

13. Becanus, G. (1580) Hermathena. In: Opera Ioan. Goropii Becani, hactenus in luce non edita. Antwerp: Plantinus.

14. Metcalf, G.J. (2013) On Language Diversity and Relationship from Bibliander to Adelung. Amsterdam, Philadelphia: John Benjamins.

15. Considine, J. (2008) Dictionaries in Early Modern Europe: Lexicography and the Making of Heritage. Cambridge et al.: Cambridge University Press.

16. Tacitus. (1969) Sochineniya $v 2-k h$ tomakh [Works in 2 Vols]. Vol. 1. Leningrad: Nauka. pp. 353-373.

17. Jones, W.J. (1999) Images of language: six essays on German attitudes to European languages from 1500 to 1800. Amsterdam, Philadelphia: John Benjamins Publishing Co.

18. Verstegan, R. (1655) A Restitution of Decayed Intelligence in Antiquities. Concerning the Most Noble and Renowned English Nation. London: Newcomb.

19. Anderson, J.H. (1996) Words that Matter: Linguistic Perception in the English Renaissance. Stanford: Stanford University Press.

20. Freydenberg, O.M. (ed.) (1996) Antichnye teorii yazyka i stilya [Ancient Theories of Language and Style]. Saint Petersburg: Aleteyya.

21. Del Bello, D. (2007) Forgotten Paths: Etymology and the Allegorical Mindset. Washington, D.C.: Catholic University of America Press.

22. Aarsleff, H. (1982) From Locke to Saussure. Essays on the Study of Language and Intellectual History. Minneapolis: University of Minnesota Press.

23. Naborn, R.A. (1995) Becanus' Etymological Methods. Voortgang. 15. pp. 79-86.

24. Cluverius, Ph. (1616) Germaniae antiquae libri tres. Leiden: Lugduni Batavorum; Elzevirius.

25. Burke, P. (2004) Languages and Communities in Early Modern Europe. Cambridge et al.: Cambridge University Press.

26. Simone, R. (2014) The Early Modern Period. In: Lepschy G. (ed.) History of Linguistics. Vol. 3. London, New York: Routledge. pp. 149-236. 